\title{
Incremental and radical open service innovation
}

Purpose Open service innovation is an emergent new service development practice, where knowledge on how to organize development work is scarce. The purpose of the present research is to identify and describe relevant archetypes of open service innovation. We view an archetype as an organizing template that includes the competence of participants, organizing co-creation among participants, and ties between participants. In particular, we are interested in how open service innovation archetypes are used for incremental and radical service innovation.

Methodology We performed a nested case study, in which we identified an industrial firm with nine open service innovation groups and performed 45 interviews with participants. For each case we first performed a within-case analysis and described how open service innovation was performed in practice. We then performed a cross-case analysis identifying similarities and differences between the open service innovation groups. Based on the crosscase analysis, we identified three archetypes for open service innovation.

Findings The nested case study identified three archetypes for open service innovation: (1) Internal Group Development; (2) Satellite Team Development, and (3) Rocket Team Development. We show that different archetypes are used for incremental and radical service innovation and that a firm can have multiple open service innovation groups using different archetypes.

Practical implications This study provides suggestions on how firms can organize for open service innovation. The identified archetypes can guide managers to set up, develop, or be part of open service innovation groups.

Originality/value This article uses open service innovation as a mid-range theory to extend existing research on new service development in networks or service ecosystems. In particular, it shows how open service innovation can be organized to develop both incremental and radical service innovations.

Paper type Research paper

Keywords: incremental innovation, new service development, nested case study, open innovation, radical innovation, service innovation

This document is the accepted manuscript version of the following article: Myhren, P., Wite11, L., Gustafsson, A., \& Gebauer, H. (2018). Incremental and radical open service innovation. Journal of Service Management, 32(2), 101-112. https://doi .org/10.1108/JSM-04-2016-0161 


\section{Incremental and radical open service innovation}

\section{Introduction}

New service development (NSD) is a key process in service firms (Edvardsson et al., 2013; Johne and Storey, 1998). It is often based on co-creating new knowledge with customers through involving them in the NSD process (Magnusson et al., 2003; Melton and Hartline, 2015). Especially in the business-to-business (B2B) market, research suggests involving other actors such as suppliers, partners, and even competitors (Syson and Perks, 2004; Lusch and Nambisan, 2015). Beyond existing models based on high-profile cases such as Google and IBM, there is scarce knowledge on how to organize open service innovation. Mina et al. (2014) argue that open innovation for services is different from products, but research provides no knowledge on taking this difference into account to organize open service innovation, which is especially relevant for industrial firms in a B2B market using open innovation for both products and services (Visnjic et al., 2016).

Open innovation takes advantage of external knowledge and access to new market channels for developing products and services. Chesbrough and Bogers (2014) viewed open innovation as an innovation process based on knowledge flows across organizational boundaries that transforms a closed development process into an open development process (Elmquist et al., 2009). Although ample research exists on open innovation for products, open service innovation has not yet been researched to the same extent (Mina et al., 2014; Randhawa et al., 2016). In a recent literature review on open innovation, Randhawa et al. (2016) argue that the service aspects of open innovation have received limited research attention, and that the conceptualization and theorization of open service innovation need to be couched in service marketing theories. In the NSD literature, concepts such as NSD in networks (Syson and Perks, 2004; Lee et al., 2009; Gottfridsson, 2014) and service innovation in ecosystems (Mele et al., 2014) have been used to describe innovation processes where 
several actors are involved and benefit from the process. These studies have made important contributions to service research by showing that NSD often take place in networks outside the traditional NSD process. Recently, Snyder et al. (2016) pointed out a major research gap concerning how firms should work with NSD to succeed with both incremental and radical service innovation. The literature on NSD in networks suggests that the network would look different, depending on if the service being developed were incremental or radical. However, present research provides no knowledge on what types of resources to use and how to organize for open service innovation; research is especially scant on how it differs between incremental and radical service innovation (Witell et al., 2016).

The purpose of the present research is to identify and describe relevant archetypes of open service innovation. Following Greenwood and Hinings (1996), we view an archetype as an organizing template including the competence of participants, organizing co-creation among participants, and ties between participants. In particular, we are interested in whether or not different archetypes for open service innovation are used for incremental and radical service innovation. In our nested case study (different case studies in one organization) of an industrial firm in a B2B market, we identified nine open service innovation groups and performed 45 interviews with the participants. Among the nine groups, we identified three archetypes for organizing open service innovation. The contributions of our research are threefold. First, we use open service innovation as a mid-range theory (Brodie and Gustafsson, 2016) to provide insight into how to organize open service innovation, thereby extending existing research on NSD in networks and service ecosystems. Second, we identify several archetypes for open service innovation. These archetypes are (1) Internal Group Development, (2) Satellite Team Development, and (3) Rocket Team Development. Thereby, we extend existing research on NSD in networks that mainly provide conceptual contributions (Mele et al., 2014) or case descriptions (Syson and Perks, 2004). Third, research on open 
service innovation has extensively been promoted as a strategy for radical service innovation (Mina et al., 2014). Our research clearly shows that it can be used for developing both incremental and radical service innovation, but that different archetypes are needed. For managers, the research shows relevance in how to put the three archetypes for open service innovation into practice.

The remainder of the manuscript is organized as follows. First, the theoretical background is presented based on the concepts of service innovation and open service innovation. Second, the method is presented and the nested case study is introduced with details on the cases and an explanation of the analysis. Third, the findings are presented with a focus on the three identified archetypes of open service innovation. Quotes and details from the nine open service innovation groups are presented to describe and explain how open service innovation is organized in practice. The manuscript ends with a discussion of the findings providing both theoretical and managerial implications.

\section{Theoretical Background}

\section{Service innovation}

Innovations consist of new combinations of existing resources, while innovating refers to the process of developing a new service (Witell et al., 2016). Arthur (2009) emphasize that innovating often concerns finding cheaper and more efficient ways or borrowing ideas from other markets and applying them in new ways (Arthur, 2009). Following this line of reasoning, Lusch and Nambisan (2015 p. 161) considered service innovation as "the rebundling of diverse resources that create novel resources that are beneficial ... to some actors in a given context.” Skålen et al. (2015) view resource integration as the core of service innovation, emphasizing both the resources and the practices through which the resources are integrated. Service innovation uses opportunities to create new combinations of resources derived from established knowledge and existing technology, taking place between multiple 
actors and networks of actors (Ballantyne et al., 2011). From a customer perspective, how the new combinations of resources are developed is not important; the key is the value co-created through the new service (Snyder et al., 2016).

Ordanini and Parasuraman (2011, p. 10) view service innovation "as the extent to which a firm's new services differ drastically from current offerings and require major changes in the application of competences.” The novelty of a radical service innovation could include a new policy, a transformed process, a new service, or a new configuration of an existing service and it can stand out through the newness of the offering or the market (Harris, McAdam, McCausland, and Reid, 2013). Based on a literature review, Snyder et al. (2016) concluded that incremental and radical are the most common categories of service innovation. However, the difference between the two is not clearly defined (Gustafsson et al., 2012). One exception is Gallouj and Weinstein (1997), who suggest that incremental service innovation means adding to or improving performance of existing characteristics of the service, while radical service innovation means introducing a new set of characteristics not related to existing ones. Based on the theoretical background, we view service innovation as recombinative, and new combinations of resources can be either incremental or radical. With incremental service innovation, we mean combinations of resources that improve performance along existing characteristics, while radical service innovation concerns combinations of resources that improve performance through a new set of characteristics.

\section{A NSD perspective on open service innovation}

Open service innovation extends existing models of NSD (Chesbrough et al., 2006). It suggests an open development process (West et al., 2014) in which exchange of technologies, ideas, and information allows competing firms to develop new services together (Wallin and Von Krogh, 2010; Elmquist et al., 2009). This strategy is used by firms such as Microsoft, GE and Google as a way to develop services together with young entrepreneurial firms. In 
literature, open innovation is still often viewed as an internal development process where external knowledge acquisition is an important activity (Elmquist et al, 2009). For open service innovation to enrich research on service innovation, we need to adopt a combination of outside-in and inside-out open service innovation.

To manage open service innovation, firms need to cooperate in strategic networks characterized by profound interactions among partners over a longer period. Piller and West (2014) stressed that firms engaged in open service innovation need to identify the right external partners with which to cooperate. In addition, they emphasized that an organizing template, i.e., how to design the relationship and the bidirectional process of innovation with external actors, needs to be in place. In open service innovation, the innovation process occurs during interactive collaboration through which knowledge creation occurs outside a particular firm in collaborative activities (Piller and West, 2014; Randhawa et al., 2016).

Piller and West (2014 p. 39) used co-creation as their theoretical foundation of open service innovation and viewed it as "an active, creative, and collaborative process between a firm and individuals during a new product/service development process in which participants contribute to a task initiated and facilitated by the firm.” In service research, co-creation has traditionally focused on the supplier-customer dyad but has expanded to incorporate cocreation among multiple actors (Vargo and Lusch, 2008). To use co-created knowledge and comprehend important external trends, a firm requires absorptive competence (Lusch et al., 2007), which is central to service innovation and the process of developing existing value propositions or creating new ones (Michel et al., 2008; Skålen et al., 2014).

If we view service innovation as a recombination of resources, open innovation should address both incremental and radical service innovation. However, present research on open service innovation emphasizes it mainly as a strategy for developing radical service innovation. Open service innovation concerns working more closely with customers to 
develop new services (Chesbrough, 2011), focusing on value rather than the product (Grönroos, 1997), and becoming embedded in the customer's organization (Oliva and Kallenberg, 2003), where customer involvement has a positive influence on the innovativeness of new services (Melton and Hartline, 2015). Higher project complexity and novelty demand greater knowledge sharing and communication intensity (Mina et al., 2014; Hsieh and Tidd, 2012). Firms that adopt open innovation reduce their boundaries with the surrounding environment, enabling innovations to move more easily among them (Elmquist et al., 2009).

We operationalize archetypes, i.e., organizing templates, of open service innovation (Piller and West, 2014) through three dimensions: competence of participants (homogeneous or heterogeneous), organizing co-creation among participants (open service innovation group or integrated development team), and ties between participants (formal or informal and deep or wide). We describe the three dimensions in detail as follows.

\section{Competence of participants}

For open service innovation projects, a key is to identify and recruit internal and external participants, focusing on individuals with relevant skills and an interest in participating (Piller and West, 2014). External participants refer to suppliers, customers, and competitors, and may also include nonprofit organizations such as universities, research labs, and citizens. A participant's profession, knowledge, creativity, and experience influence his or her ability and willingness to participate in open innovation projects (Füller et al., 2009; Piller and West, 2014). If the participants' competencies are homogeneous, it means that they have common educational background and knowledge. A multidisciplinary, cross-functional approach to open service innovation uses diversity as an intellectual resource to facilitate sharing ideas and knowledge across participants (Melton and Hartline, 2013). In other words, the team 
captures participants' capabilities and consists of individuals with a diverse set of knowledge and skills (Edvardsson et al., 2013), i.e., with heterogeneous competences.

\section{Organizing co-creation among participants}

A firm adopting open service innovation assumes that the NSD process will be redesigned (Giannopolou et al., 2011). Research on NSD suggests alternative development processes based on stage-gate processes, using between three to 15 phases (Edvardsson et al., 2013; Johne and Storey, 1998). The process often starts with an idea and ends in market launch and implementation. In the present research, we view the NSD process through four stages: market sensing, development, sales, and delivery (Kindström and Kowalkowski, 2009). This process covers a broader range of activities compared with traditional NSD processes, emphasizing that later NSD stages (such as sales and delivery) must be given greater importance to successfully develop services.

We differentiate between open innovation groups and integrated development teams. It is essential that an open innovation group cooperates across organizational boundaries and disciplines (Lin and Hsieh, 2014), such as that external actors in the value network or the service ecosystem are involved in the development work. An open innovation group has participants from different organizations that meet during a longer period, whereas an integrated development team is a group that performs the operational work of developing a new service. Melton and Hartline (2015) argue that the greater the use of integrated development teams across the stages of the NSD process, the greater the use of their diverse skills and perspectives, and this the easier to draw on organizational and external resources. One particular characteristic of an open service innovation group is that it does not replace integrated development teams (Edvardsson et al., 2013; Melton and Hartline, 2015), but complements the process, building on newly created knowledge, used later by integrated development teams (Hsieh and Tidd, 2012). An open innovation group and an integrated 
development team can include the same participants or consist of different ones. The intensity and the richness of the interactions between participants determine how much open service innovation groups or integrated development teams can recombine resources to find solutions to problems and, finally, create new services (Paulraj et al., 2008).

\section{Ties between participants}

Frequently, service innovation results from repeated interactions between the firms and participants involved (Simard and West, 2006), making trust an important coordination mechanism (Powell, 1990). To gain knowledge from external cooperations, a firm forms different types of ties with participants (Powell et al., 1999; Baum et al., 2000). The ties are formal or informal (Vanhaverbeke, 2006), and deep or wide (Simard and West, 2006); different types of ties provide different types of knowledge (Powell et al., 1999; Baum et al., 2000). Formal ties are planned channels of knowledge transfer between organizations, often ruled by agreements or contracts, enabling firms to fill internal knowledge gaps. Typically, formal ties are incorporated in open innovation strategies (Simard and West, 2006). Informal ties involve unplanned or unforeseen actions, such as labor movements, between firms and organizational affiliations, which can lead to unexpected knowledge spillovers (Simard and West, 2006). Because service businesses are highly interactive and relational, they favor informal rather than formal ties (Mina et al., 2014).

When firms embed themselves in open service innovation groups and establish trust in one another, the ties deepen. Deeper ties enable valuable information and knowledge exchange, positively affecting the outcome (Hsueh et al., 2010; Uzzi, 1996, 1997). However, there can be a threshold created when deepened ties enhance the risks of over-embeddedness such that the open service innovation group becomes closed to external information (Simard and West, 2006; Uzzi, 1997). Open service innovation groups with deep ties are characterized by redundant information that overlaps with existing knowledge bases, leading to incremental 
innovations (Vanhaverbeke, 2006). To overcome the shortcomings of over-embeddedness, open service innovation groups can form wide ties, or arm's-length ties, based on sporadic rather than frequent interactions between participants (Granovetter, 1973; Simard and West, 2006). Open service innovation groups with wide ties give participating firms access to nonredundant information, increasing innovation potential (Granovetter, 1973; Vanhaverbeke, 2006).

\section{Method}

A nested case study

To identify and describe archetypes of open service innovation, we employed a nested case study approach (Yin, 2014; Gibbert and Ruigrok, 2010). Case study research is beneficial to develop theory by observing actual practice (Meredith, 1998). In addition, cases can be used as illustrations or to further develop existing theory by pointing to and exploring research gaps (Siggelkow, 2007). A single firm may involve a number of different cases that enable comparisons that clarify whether an emergent result can be consistently replicated (Eisenhardt and Graebner, 2007; Voss et al., 2002). We performed an in-depth study of multiple open service innovation groups in a case firm. The choice to perform a nested case study in a single firm was based on that: (1) the case firm has been able to grow their business during the last 17 years, with the new services behind this growth all developed through open service innovation; (2) the research team was promised full access to the open service innovation groups, including interviews, observations, and internal documentation. The choice of a nested case study allowed us to do cross-case comparisons, where the external environment was the same or similar across the cases. As a consequence, the similarities and differences across the cases should be attributed to the internal environment in the open service innovation groups. After getting access, we identified nine open service innovation groups in the case firm. 


\section{Study object}

The case firm (called innovator firm) is owned jointly by six Swedish multinational pulp and paper companies. It has formed nine open service innovation groups: delivery contracts, inventory database, structural engineering, mechanical engineering, electrical engineering, instrumental engineering, pipe engineering, surface protection, and safety. All groups are long-lived and consist of a project manager and participants from the six owner companies, with participants from other industries, such as automotive, mining, steel, and paint/surface protection.

The Swedish innovator firm further develops the concepts from these nine open service innovation groups and introduces services to the market. The open service innovation groups perform the first two stages (market sensing and development), and the innovator firm performs the last two stages (sales and delivery) (Kowalkowski and Kindström, 2009). The project manager has a crucial role as an innovation intermediary (Howells, 2006), i.e., as a link between the open service innovation groups and the marketing and scaling up activities performed by the innovator firm. The developed services can be described as services for the B2B market for industrial services, including education services, provision of standards, database services, and certification services.

\section{Data collection}

In data collection, we used triangulation through multiple methods (Voss et al., 2002). First, we performed seven in-depth interviews with project managers at the innovator firm responsible for the open service innovation groups. The interviews were conducted with the guidance of a semi-structured interview guide designed to gain a better understanding of the open service innovation groups, the participants, and development practices. In addition, the project managers were interviewed about the roles of the participants and the project manager. 
Second, during 20 site visits, we performed 38 in-depth interviews with participants of the open service innovation groups (33 participants from the pulp and paper industry, one participant from the steel industry, one paint manufacturer, one surface protection inspector, and two technical consultants). The in-depth interviews were preceded by a purposive nested sampling (Miles et al., 2014) of participants with good knowledge of the development work. The interviews followed a semi-structured interview guide to reveal participants' views of the development work and the three dimensions of the archetypes of open service innovation (competence of participants, organizing co-creation among participants, and ties between participants). Altogether, we performed 45 in-depth interviews with participants in nine different open service innovation groups. The interviews were 50 to 90 minutes long and were audio recorded. All interviews were transcribed verbatim, resulting in 689 pages of written text. See Table 1 for details on the different open service innovation groups, participants, and interviews conducted.

Third, one of the authors visited six meetings in the open service innovation groups. Secondary sources were also used, such as historical documentation on the development of the open service innovation groups, strategy documents of the innovator firm and the open service innovation groups, and online information (Visconti, 2010). The publicly accessible information and internal documents, combined with the data gathered through the interviews, created opportunities for data source triangulation (Miles et al., 2014; Yin, 2014; Visconti, 2010).

- Insert Table 1 about here -

\section{Data analysis}

Data analysis was divided in two parts, a within-case analysis followed by a cross-case analysis. First, the transcribed interviews were imported into QSR NVivo and inductively coded, categorized, and analyzed using a within-case approach. For each case, we created a 
description of the open service innovation group based on the three dimensions derived in the theoretical framework. We used both text and visual displays to get an understanding of how open service innovation appeared in practice. To search for data patterns, we also used memos, notes from the interviews, observations from the meetings, information from secondary sources, and tables. For transparency of how the archetypes were derived, the appendix includes quotes for each open innovation group on the investigated dimensions.

Second, the data analysis continued with a cross-case analysis. The researchers matched, contrasted, and sorted different descriptions of the open service innovation groups, resulting in a set of tables and templates on how to organize open service innovation (Yin, 2014; Miles et al., 2014). We followed an iterative process, where the graphical displays were sorted into archetypes based on their distinguishing features. The suggested archetypes were analyzed based on the case descriptions, and re-sorting of the cases was performed until an agreement on the archetypes could be reached. We identified the purpose of the group, competence of participants, organizing co-creation among participants, and ties between participants. This iterative process among the members of the research team tested the credibility of the findings (Hirschman, 1986). We revisited the innovator firm's project managers several times during the research process to confirm our findings and increase the external validity of the research.

\section{Findings}

The innovator firm organizes the open service innovation groups, turning their ideas and concepts into commercial services. Each of the open service innovation groups is organized as a team of participants facilitated by a project manager from the innovator firm.

When analyzing the nine open service innovation groups, we identified three archetypes of open service innovation: (1) Internal Group Development, (2) Satellite Team Development, and (3) Rocket Team Development. Of the nine open innovation groups, at 
least two innovation groups used each archetype. There are some general traits across the three archetypes of open service innovation: (a) it is the participants in the groups who make decisions about the innovations to pursue, not the project manager; (b) the participants are not allowed to interfere with the innovator firm's business model; and finally (c) open service innovation group participants were not paid (Boudreau and Lakhani, 2009). In the following, we will discuss the three archetypes in more detail, see Figure 1.

- Insert Figure 1 about here -

\section{Archetype 1: Internal Group Development}

The first archetype, “Internal Group Development,” is used by three open service innovation groups to perform incremental service innovation. Three groups work with delivery contract (DC), inventory database (ID), and structural engineering (SE), mainly to improve existing services. For each open service innovation group, participant competences are homogeneous; in other words, participants have common educational backgrounds and knowledge. The concepts used have the same meaning for all participants, and the discussion can be very detailed. In the DC group, all participants are purchase managers or business lawyers. A participant described the group: "We need people with profound experience of procurement work and often it is purchase managers, and normally two to three business lawyers.” The ID group members were purchasing managers or logistics managers, and in the SE group the members were structural engineers or technical consultants.

The development work is performed within the open service innovation groups and concerns improvement of existing characteristics. In the DC group, development work concerns maintenance and improvements of delivery contracts. One member described the situation as, "I rather say we work together but sometimes we also work in sub-groups [within the innovation group] if certain competence is needed.” The ID group's objective is to maintain and improve a database, and most of the development occurs within the open service 
innovation group. When new functionality is required, it occasionally forms development teams with super-users. Due to resource scarcity, development is often performed within the open service innovation groups. One participant in the structural engineering (SD) group stated, “We don’t have the time or energy to engage in finding solutions, making calculations and blueprints so we have invited two technical consultants to the group.”

In this archetype, ties among participants can be characterized as formal and deep. Both the DC and ID groups have narrow objectives to improve a specific service with defined roles and shared competences among participants. Repeated interactions over several years create trust among the participants. One participant in the open service innovation group for delivery contracts described the situation as, "When you sit there [in the open service innovation group], it almost feels like you are one company, then it's the open service innovation group that matters, then you sort of represent the innovator firm.”

\section{Archetype 2: Satellite Team Development}

The second archetype, "Satellite Team Development," is used by four of the open service innovation groups for incremental service innovation. The four groups are mechanical engineering (ME), instrument engineering (IE), electrical engineering (EE), and pipe engineering (PE); they are dedicated to improving existing services with a focus on technical standards and guidelines. The participants worked in the pulp and paper industry and had homogeneous competences.

Development work follows a standardized process for incremental service innovation; work starts with a suggestion from the open service innovation groups, which then set up projects, and form integrated development teams. One participant from the ME group explains, "We have something we call 'A standard for a standard' and that's a structured way how to produce technical standards.” The integrated development teams consist of the project manager and a member from the open service innovation group, and also technical specialists 
included to perform service improvements. When the project is completed, the integrated development teams present the results to the open service innovation groups for approval.

In this archetype, the open service innovation groups rely on the deep trust developed through many years of cooperation. One participant described the situation as "I've never noticed that we're supposed to keep information for yourself, if you have experienced anything advantageous you rather want to share that to others to make their work easier.” As a consequence, the ties for Satellite Team Development are less formal than for Internal Group Development.

\section{Archetype 3: Rocket Team Development}

Two open service innovation groups, surface protection (SP) and safety (S), use the third archetype, "Rocket Team Development,” to perform radical service innovation. The SP group has adopted a lifecycle perspective on surface protection and formed a mission to develop methods for creating a safe, efficient, and economically justifiable work environment. The competences of the participants are heterogeneous; one participant explains it as follows: "It's the broadest set of competences there is to get in the surface protection group. That result in standards highly respected among all stakeholders in the [surface protection] society.”

In the SP group, senior participants initiate radical service innovation projects through putting together an integrated development team. When there is a solution, it is presented to the rest of the SP group. Integrated development teams in the S group perform the development work to find new services regarding safety. Results of a pre-study determine whether to start a development project or not. Compared with the other archetypes, the Rocket Team Development's ties are wider and less formal. On a formal-informal continuum, both the SP and the S open service innovation groups are informal. 


\section{Discussion and implications}

In the following section, we elaborate on the similarities and differences between the identified archetypes for open service innovation. In particular, we discuss how open service innovation can be used for both incremental and radical service innovation. We end by summarizing the theoretical and managerial implications, as well as limitations and suggestions for further research.

Three archetypes for organizing open service innovation were identified with distinguishing characteristics on the dimensions of the organizing template, such as competence of participants, organizing co-creation among participants, and ties between participants (see Table 2). Two of the archetypes, Internal Group Development and Satellite Group Development, fit incremental service innovation, while Rocket Group Development fits radical service innovation. Previous research has emphasized radical service innovation and used cases such as Xerox and IBM for theory development (Chesbrough, 2013). In contrast, the present research identifies open service innovation as a relevant strategy for incremental service innovation. However, it cannot be organized as described in previous research, since existing organizing templates are based on radical service innovation.

A key for open service innovation is to identify participants with the right competencies (Piller and West, 2014). The typical participant is an expert in, and has a high degree of, use knowledge (Piller and West, 2014). This study identifies two different competence setups, homogenous versus heterogeneous. In open service innovation groups that focus on incremental service innovation, homogenous competence and educational background are preferred because in-depth discussions are required for service improvements (Internal Group Development and Satellite Team Development). If open service innovation groups focus on radical service innovation, heterogeneous competences and educational background are superior (Rocket Team Development). This is consistent with previous research on NSD in a 
network perspective, suggesting that radical innovation may require access to different types of resources (Syson and Perks, 2004).

In open service innovation, the development team must be organized differently, dependent on the degree of novelty (see Froehle et al., 2000; Edvardsson et al., 2013). In general, the use of integrated development teams contributes to the effectiveness of NSD (Froehle et al., 2009). Radical service innovation requires a higher intensity of interactions among participants compared to incremental service innovation (Hsieh and Tidd, 2012). We argue for the use of development within open service innovation groups when: (1) the focus is on incremental service innovation; (2) there is scarcity in specific competences; or (3) all competences exist within the group. We argue for the use of integrated development teams: (1) to decrease development time through performing several incremental service innovation projects in parallel; or (2) when the tasks concern radical service innovation and require heterogeneous competences.

In addition to influencing what and how, project novelty also influences how participants interact in an open service innovation project. In particular, projects focusing on incremental service innovation should involve participants with formal and deep ties (Simard and West, 2006). First, the roles in the development process rely on each participant's knowledge and skills. Second, participants must reveal what they know and share it with the rest of the group. Because each development team participant knows his or her role, one advantage is reduced development time. In situations in which an open service innovation group works on radical service innovation, a wider setup of ties enables knowledge spillover (Granovetter, 1973). Some participants are permanent members, and some are recruited specifically for a particular project. These wider ties are favorable for identifying the different layers of knowledge needed to develop radical service innovation.

- Insert Table 2 about here - 


\section{Theoretical implications}

Our research makes several important contributions to extend research on service innovation. Recent conceptualizations of service innovation as recombination of resources (Lusch and Nambisan, 2015) fit well with theories on open service innovation. However, open service innovation is not well conceptualized, and theories on service marketing should enrich theory development (Randhawa et al., 2016). However, open service innovation has not been extensively used as a concept or scrutinized in service research. This study addresses the research gap on how to organize open service innovation (or service innovation in networks) (Syson and Perks, 2004), and how open service innovation differs between incremental and radical service innovation (Snyder et al., 2016). The present research provides an empirical investigation, and develops terminology to enrich the discussion and theory development on open service innovation. In particular, the present research makes three important theoretical contributions.

First, recent theoretical contributions on service innovation (such as Lusch and Nambisan (2015) and Mele et al. (2014)) on a general level suggest that service innovation takes place in a service ecosystem, often through processes similar to open innovation. In contrast, the present research uses open service innovation as a mid-range theory (Brodie and Gustafsson, 2016) to bridge theoretical rigor and managerial relevance (Gustafsson et al., 2015). Revisiting research agendas from 1990, Gustafsson and Bowen (2017) suggest that service research still needs more contingency theories to move away from global assertions to understand what kind of organization, under what conditions are needed (see also Voss et al. (2016)). In this tradition, the present research can provide insights into how to organize development work on service innovation within service ecosystems, and how ways of organizing might differ between incremental and radical service innovation. 
Second, this study shows that open service innovation is not built on one archetype but that there is a range of organizing templates that fit different types of development work. This extends previous research on open service innovation that thus far has focused on differences in open innovation for products and services (Mina et al., 2014). The nested case study identifies three conceptually and empirically different archetypes for open service innovation. These archetypes are "Internal Group Development," "Satellite Team Development," and "Rocket Team Development" that differ in the dimensions of the organizing template. This contribution answers the call for service marketing to enrich theory development on open service innovation (Randhawa et al., 2016) and it complements existing models of NSD that often strictly follows a stage-gate approach (Edvardsson et al., 2013).

Third, previous research on open service innovation has focused on radical service innovation (Chesbrough, 2011; Mina et al., 2014). However, the present research suggests that open service innovation can be a strategy for incremental service innovation. In fact, two of the identified archetypes are used for incremental service innovation. In addition to previous research in NSD showing that different sets of resources are needed for incremental and radical service innovation (Syson and Perks, 2004), the present research shows that there are additional differences on how to organize the development work and how to enable interaction between participants. Especially in the era of platforms (Lusch and Nambisan, 2015), open service innovation can become a strategy of cooperation to create a sustainable service business (Visnjic et al., 2016). Open service innovation reduces boundaries between firms, enabling innovations to move easily among them. This is beneficial for both incremental and radical service innovation, because both must be further improved after market introduction to build a sustainable service business and uphold a competitive advantage. 


\section{Managerial implications}

This study provides guidance on how firms can organize for open service innovation. The identified archetypes can guide managers who plan to set up, develop, and be part of open service innovation. Organizations can run parallel open innovation groups, where some archetypes are suited for incremental service innovation and others for radical service innovation. Over time, open service innovation groups should switch between different archetypes, dependent on the development project, i.e., suggesting a modular model for open service innovation; see, e.g., Jaakola et al. (2017).

The Internal Group Development archetype is designed for incremental service innovation. One formula is to gather senior participants within the area of interest, obtain agreement on what needs to be done, and run all development work within the group. The Satellite Team Development archetype suits a narrow objective focusing on standardized incremental service innovation. Due to a larger number of tasks, more participants need to be involved using less formal ties than for Internal Group Development. The development work occurs in integrated development teams of specialists and, consequently, greater coordination between the open service innovation group and the integrated development teams is required. The Rocket Team Development archetype concerns projects for radical service innovation. A cross-functional team of senior participants with heterogeneous competences should be put together. This type of open service innovation group should have informal and wide ties among participants. The development work can occur within the group or be outsourced to an integrated development team.

\section{Limitations and further research}

There are several limitations to this research. First, a study of the nine open service innovation groups was performed in a single firm working in a B2B context. Although a nested case study approach produces benefits from a research design perspective, we acknowledge the 
limited generalizability of our results based on nine cases. In addition, we have been cautious not to over-interpret the meaning of individual events. We do not claim to have identified all existing archetypes for open service innovation, and we hope that further research in additional empirical contexts can enrich the identified set of archetypes. Further, we have focused on three dimensions of the organizational template, and further research could enrich our archetypes through analyzing their differences and similarities in additional dimensions. Following this line of reasoning, enriching research on open service innovation using service dominant logic could be beneficial, especially to couch archetypes within the role of institutions for service innovation (Vargo et al., 2015).

Second, the study concerned recent open service innovation projects. We did not investigate if a service innovation group could switch between different archetypes of open service innovation or if groups were limited to using a specific archetype as their organizational template. In addition, although we used observations at group meetings in the different open service innovation groups, a study performed in real time, longitudinally, rather than relying on retrospectives, could have provided additional insights.

Further large-scale research studies on open service innovation would be beneficial to identify additional contingencies beyond incremental and radical open service innovation. Are there differences between cultures, industries and firms, and are there differences between successful and non-successful open service innovation projects?

\section{References}

Arthur, W.B. (2009), The nature of technology: What it is and how it evolves, Simon and Schuster.

Ballantyne, D., Frow, P., Varey, R. J., \& Payne, A. (2011), "Value propositions as communication practice: Taking a wider view,” Industrial Marketing Management, Vol. 40 No. 2, pp. 202-210.

Brodie, R.J., \& Gustafsson, A. (2016), "Enhancing theory development in service research,” Journal of Service Management, Vol. 27 No. 1, pp. 2-8.

Baum, J.A.C., Calabrese, T., \& Silverman, B.S. (2000), “Don’t go it alone: Alliance network composition and startups' performance in Canadian biotechnology," Strategic Management Journal, Vol. 21 No. 3, pp. 267-294. 
Boudreau, K.J. \& Lakhani, K. (2009), "How to manage outside innovation: Competitive markets or collaborative communities?,” MIT Sloan Management Review, Vol. 50 No. 4, pp. 69-75.

Chesbrough, H.W. \& Bogers, M. (2014), "Explication open innovation: Clarifying an emerging paradigm for understanding innovation,” In H. Chesbrough, W. Vanheverbeke, \& J. West (Eds.), New frontiers in open innovation (1st ed.), Oxford: Oxford University Press, pp. 3-28.

Chesbrough, H.W., Vanhaverbeke, W., \& West, J. (2006), Open innovation: Researching a new paradigm (1st ed.). Oxford: Oxford University Press.

Chesbrough, H.W. (2011), Open service innovation (1st Ed.). San Francisco: Jossey-Bass.

Edvardsson, B., Meiren, T., Schäfer, A. \& Witell, L. (2013), "Having a strategy for new service development - does it really matter?,” Journal of Service Management, Vol. 24 No. 1, pp. 25-44.

Eisenhardt, K.M. \& Graebner, M.E. (2007), “Theory building from cases: Opportunities and challenges,” Academy of Management Journal, Vol. 50 No. 1, pp. 25-32.

Elmquist, M., Fredberg, T., \& Ollila, S. (2009), "Exploring the field of open innovation," European Journal of Innovation Management, Vol. 12 No. 3, pp. 326-345.

Enkel, E., Bell, J., \& Hogenkamp, H. (2011), “Open innovation maturity framework,” International Journal of Innovation Management, Vol. 15 No. 6, pp. 1161-1189.

Froehle, C.M., Roth, A.V., Chase, R.B., \& Voss, C.A. (2000), "Antecedents of new service development effectiveness: An exploratory examination of strategic operations choices," Journal of Service Research, Vol. 3 No. 1, pp. 3-17.

Füller, J., Mühlbacher, H., Matzler, K., \& Jawecki, G. (2009), “Consumer empowerment through Internet-based co-creation,” Journal of Management Information Systems, Vol. 26 No. 3, pp. 71-102.

Gallouj, F. \& Weinstein, O. (1997), “Innovation in services,” Research Policy, Vol. 26 No. 45, pp. 537-556.

Giannopoulou, E., Yström, A., \& Ollila, S. (2011), “Turning open innovation into practice: Open innovation research through the lens of managers," International Journal of Innovation Management, Vol. 15 No. 3, pp. 505-524.

Gibbert, M. \& Ruigrok, W. (2010), "The "what” and "how" of case study rigor: Three strategies based on published work," Organizational Research Methods, Vol. 13 No. 4, pp. 710-737.

Gottfridsson, P. (2014), “Different actors’ roles in small companies service innovation,” Journal of Services Marketing, Vol. 28 No. 7, pp. 547-557.

Granovetter, M.S. (1973), “The strength of weak ties,” American Journal of Sociology, Vol. 78 No. 6, pp. 1360-1380.

Greenwood, R. \& Hinings, C.R. (1996), "Understanding radical organizational change: Bringing together the old and the new institutionalism," Academy of Management Review, Vol. 21 No. 4, pp. 1022-1054.

Grönroos, C. (1997), "Value-driven relational marketing: From products to resources and competencies,” Journal of Marketing Management, Vol. 13 No. 5, pp. 407-419.

Gustafsson, A., Kristensson, P. and Witell, L. (2012), "Customer co-creation in service innovation: a matter of communication?” Journal of Service Management, Vol. 23 No. 3, pp. 311-327.

Gustafsson, A., Aksoy, L., Brady, M.K., McColl-Kennedy, J.R., Sirianni, N. J., Witell, L., \& Wuenderlich, N.V. (2015), "Conducting service research that matters," Journal of Services Marketing, Vol. 29 No. 6/7, pp. 425-429. 
Gustafsson, A. \& Bowen, D. (2017), “The curious case of interdisciplinary research deficiency: Cause or symptom of what truly ails us?” Journal of Business Research, In press.

Harris, R., McAdam, R., McCausland, I., \& Reid, R. (2013), "Levels of innovation within SMEs in peripheral regions: The role of business improvement initiatives,” Journal of Small Business and Enterprise Development, Vol. 20 No. 1, pp. 102-124.

Hirschman, E.C. (1986), "Humanistic inquiry in marketing research: Philosophy, method, and criteria,” Journal of Marketing Research, Vol. 23 No. 3, pp. 237-249.

Howells, J. (2006), "Intermediation and the role of intermediaries in innovation," Research Policy, Vol. 35 No. 5, pp. 715-728.

Hsieh, K. \& Tidd, J. (2012), “Open versus closed new service development: The influences of project novelty,” Technovation, Vol. 32 No. 11, pp. 600-608.

Hsueh, J.-T., Lin, N.-P., \& Li, H.-C. (2010), “The effects of network embeddedness on service innovation performance,” Service Industries Journal, Vol. 30 No. 10, pp. 17231736.

Jaakkola, E., Meiren, T., Witell, L., Edvardsson, B., Schäfer, A., Reynoso, J., Sebastiano, R. \& Weitlaner, D. (2017), "Does one size fit all? New service development across different types of services,” Journal of Service Management, Vol. 28 No. 2, pp. 329-347.

Johne, A. \& Storey, C. (1998), "New service development: A review of the literature and annotated bibliography,” European Journal of Marketing, Vol. 32 No. 3, pp. 184-251.

Kindström, D. \& Kowalkowski, C. (2009), "Development of industrial service offerings: A process framework,” Journal of Service Management, Vol. 20 No. 2, pp. 156-172.

Lee, R.P., Ginn, G.O., \& Naylor, G. (2009), “The impact of network and environmental factors on service innovativeness," Journal of Services Marketing, Vol. 23 No. 6, pp. 397-406.

Lin, F.R. and Hsieh, P.S. (2014), “Analyzing the sustainability of a newly developed service: An activity theory perspective,” Technovation, Vol. 34 No. 2, pp. 113-125.

Lusch, R.F. \& Nambisan, S. (2015), “Service innovation: A service-dominant logic perspective,” MIS Quarterly, Vol. 39 No. 1, pp. 155-175.

Lusch, R.F., Vargo, S.L., \& O’Brien, M. (2007), “Competing through service: Insights from service-dominant logic,” Journal of Retailing, Vol. 83 No. 1, pp. 5-18.

Magnusson, P.R., Matthing, J., \& Kristensson, P. (2003), "Managing user involvement in service innovation: Experiments with innovating end users," Journal of Service Research, Vol. 6 No. 4, pp. 111-124.

Mele, C., Colurcio, M., \& Russo-Spena, T. (2014), "Research traditions of innovation: Goods-dominant logic, the resource-based approach, and service-dominant logic," Managing Service Quality, Vol. 24 No. 6, pp. 612-642.

Melton, H.L. \& Hartline, M.D. (2013), “Employee collaboration, learning orientation, and new service development performance,” Journal of Service Research, Vol. 16 No. 1, pp. 67-81.

Melton, H., \& Hartline, M. D. (2015), “Customer and employee co-creation of radical service innovations,” Journal of Services Marketing, Vol. 29 No.2, pp. 112-123.

Meredith, J. (1998), "Building operations management theory through case and field research,” Journal of Operations Management, Vol. 16 No. 4, pp. 441-454

Michel, S., Brown, S.W., \& Gallan, A.S. (2008), "Service-logic innovations: How to innovate customers, not products,” California Management Review, Vol. 50 No. 3, pp. 49-65.

Miles, M.B., Huberman, M.A., \& Saldana, J. (2014), Qualitative data handbook, a methods sourcebook (3rd ed.), Thousand Oaks, California: Sage Publications, Inc.

Mina, A., Bascavusoglu-Moreau, E., \& Hughes, A. (2014), “Open service innovation and the firm's search for external knowledge,” Research Policy, Vol. 43 No. 5, pp. 853-866. 
Oliva, R. \& Kallenberg, R. (2003), "Managing the transition from products to services," International Journal of Service Industry Management, Vol. 14 No. 2, pp. 160-172.

Ordanini, A., \& Parasuraman, A. (2010), "Service innovation viewed through a servicedominant logic lens: a conceptual framework and empirical analysis," Journal of Service Research, Vol. 14 No.1, pp. 3-23.

Paulraj, A., Lado, A.A., \& Chen, I.J. (2008), “Inter-organizational communication as a relational competency: Antecedents and performance outcomes in collaborative buyersupplier relationships,” Journal of Operations Management, Vol. 26 No. 1, pp. 45-64.

Piller, F. \& West, J. (2014), "Firms, users and innovation: An interactive model of coupled open innovation,” In H. Chesbrough, W. Vanheverbeke, \& J. West (Eds.), New frontiers in open innovation (1st ed.), Oxford: Oxford University Press, pp. 29-49.

Powell, W.W. (1990), “Neither market nor hierarchy: Network forms of organization,” In B.M. Staw \& L.L. Cummings (Eds.), Research in Organizational Behavior, Vol. 12, Greenwich, CT: JAI Press.

Powell, W.W., Koput, K.W., Smite-Doerr, L., \& Owen-Smith, J. (1999), “Network position and firm performance: Organizational returns to collaboration in the biotechnology industry,” Research in the Sociology of Organizations, Vol. 16, pp. 129-159.

Randhawa, K., Wilden, R. and Hohberger, J. (2016), “A bibliometric review of open innovation: Setting a research agenda," Journal of Product Innovation Management, Vol. 33 No. 6, pp. 750-772.

Siggelkow, N. (2007), "Persuasion with case studies,” Academy of Management Journal, Vol. 50 No. 1, pp. 20-24.

Simard, C. \& West, J. (2006), "Knowledge networks and the geographic locus of innovation," In H. Chesbrough, W. Vanheverbeke, \& J. West (Eds.), Open innovation: Researching a new paradigm (1st ed.), Oxford: Oxford University Press, pp. 220-240.

Skålén, P., Gummerus, J., Koskull, C., \& Magnusson, P. (2014), “Exploring value propositions and service innovation: A service-dominant logic study,” Journal of the Academy of Marketing Science, Vol. 43 No. 2, pp. 137-158.

Snyder, H., Witell, L., Gustafsson, A., Fombelle, P., \& Kristensson, P. (2016), "Identifying categories of service innovation: A review and synthesis of the literature," Journal of Business Research, Vol. 69 No. 7, pp. 2401-2408.

Syson, F. and Perks, H. (2004), "New service development: a network perspective,” Journal of Services Marketing, Vol. 18 No. 4, pp. 255-266.

Uzzi, B. (1996), “The sources and consequences of embeddedness for the economic performance of organizations: The network effect," American Sociological Review, Vol. 61 No. 4, pp. 674-698.

Uzzi, B. (1997), "Social structure and competition in interfirm networks: The paradox of embeddedness,” Administrative Science Quarterly, Vol. 42 No. 1, pp. 35-67.

Vanhaverbeke, W. (2006), "The interorganizational context of open innovation,” In H.W. Chesbrough, W. Vanheverbeke, \& J. West (Eds.) Open innovation: Researching a new paradigm (1st ed.), Oxford: Oxford University Press, pp. 205-219.

Vargo, S.L., \& Lusch, R.F. (2008), "Service-dominant logic: Continuing the evolution,” Journal of the Academy of Marketing Science, Vol. 36 No. 1, pp. 1-10.

Vargo, S.L., Wieland, H., \& Akaka, M.A. (2015), "Innovation through institutionalization: A service ecosystems perspective,” Industrial Marketing Management, Vol. 44 No. 1, pp. 63-72.

Visconti, L.M. (2010), "Ethnographic Case Study (ECS): Abductive modeling of ethnography and improving the relevance in business marketing research,” Industrial Marketing Management, Vol. 39 No. 1, pp. 25-39. 
Visnjic, I., Wiengarten, F., \& Neely, A. (2016), “Only the brave: Product innovation, service business model innovation, and their impact on performance," Journal of Product Innovation Management, Vol. 33 No. 1, pp. 36-52.

Voss, C., Tsikriktsis, N., \& Frohlich, M. (2002), "Case research in operations management," International Journal of Operations \& Production Management, Vol. 22 No. 2, pp. 195219.

Voss, C., Perks, H., Sousa, R., Witell, L., \& Wünderlich, N. V. (2016), "Reflections on context in service research,” Journal of Service Management, Vol. 27 No. 1, pp. 30-36.

Wallin, M.W. \& von Krogh, G. (2010), "Organizing for open innovation: Focus on the integration of knowledge,” Organizational Dynamics, Vol. 39 No. 2, pp. 145-154.

West, J., Salter, A., Vanhaverbeke, W., \& Chesbrough, H.W. (2014), “Open innovation: The next decade,” Research Policy, Vol. 43 No. 5, pp. 805-811.

Witell, L., Snyder, H., Gustafsson, A., Fombelle, P. and Kristensson, P. (2016), "Defining service innovation: A review and synthesis,” Journal of Business Research, Vol. 69 No. 8, pp. 2863-2872.

Yin, R.K. (2014), Case study research, design and methods (5th ed.), Thousand Oaks, California: Sage Publications, Inc. 
Table 1: An overview of the studied open service innovation groups.

\begin{tabular}{|c|c|c|c|c|c|}
\hline Innovation group & The Service & Tasks & $\begin{array}{l}\text { Types of } \\
\text { participants }\end{array}$ & Participants & Interviews \\
\hline $\begin{array}{l}\text { Delivery } \\
\text { contract (DC) }\end{array}$ & Contracts & $\begin{array}{l}\text { Maintain, improve } \\
\text { existing service }\end{array}$ & Senior & 11 & 5 \\
\hline Inventory database (IB) & Database & $\begin{array}{l}\text { Maintain, improve } \\
\text { existing service }\end{array}$ & Senior, specialist & 10 & 5 \\
\hline $\begin{array}{l}\text { Structural engineering } \\
\text { (SE) }\end{array}$ & $\begin{array}{l}\text { Standards, } \\
\text { guidelines and } \\
\text { blueprints }\end{array}$ & $\begin{array}{l}\text { Maintain, improve } \\
\text { existing and develop } \\
\text { new services }\end{array}$ & $\begin{array}{l}\text { Senior, specialist, } \\
\text { consultant }\end{array}$ & 9 & $5 *$ \\
\hline $\begin{array}{l}\text { Mechanical engineering } \\
\text { (ME) }\end{array}$ & $\begin{array}{l}\text { Standards, } \\
\text { guidelines and } \\
\text { blueprints }\end{array}$ & $\begin{array}{l}\text { Maintain, improve } \\
\text { existing and develop } \\
\text { new services }\end{array}$ & Senior, specialist & 9 & 5 \\
\hline $\begin{array}{l}\text { Instrument engineering } \\
\text { (IE) }\end{array}$ & $\begin{array}{l}\text { Standards, } \\
\text { guidelines and } \\
\text { blueprints }\end{array}$ & $\begin{array}{l}\text { Maintain, improve } \\
\text { existing and develop } \\
\text { new services }\end{array}$ & Senior, specialist & 7 & $5 * *$ \\
\hline $\begin{array}{l}\text { Electrical engineering } \\
\text { (EE) }\end{array}$ & $\begin{array}{l}\text { Standards, } \\
\text { guidelines and } \\
\text { blueprints }\end{array}$ & $\begin{array}{l}\text { Maintain, improve } \\
\text { existing and develop } \\
\text { new services }\end{array}$ & Senior, specialist & 10 & $5 * *$ \\
\hline $\begin{array}{l}\text { Pipe } \\
\text { engineering (PE) }\end{array}$ & $\begin{array}{l}\text { Standards, } \\
\text { guidelines and } \\
\text { blueprints }\end{array}$ & $\begin{array}{l}\text { Maintain, improve } \\
\text { existing and develop } \\
\text { new services }\end{array}$ & $\begin{array}{l}\text { Senior, specialist, } \\
\text { consultant }\end{array}$ & 12 & 5 \\
\hline Surface protection (SP) & $\begin{array}{l}\text { Standards and } \\
\text { investigations }\end{array}$ & $\begin{array}{l}\text { Maintain, improve } \\
\text { existing and develop } \\
\text { new services with a } \\
\text { lifecycle-perspective on } \\
\text { surface protection }\end{array}$ & $\begin{array}{l}\text { Senior, specialist, } \\
\text { expert, } \\
\text { manufacturer, } \\
\text { entrepreneur }\end{array}$ & 14 & $6^{*}$ \\
\hline Safety (S) & $\begin{array}{l}\text { Educations and } \\
\text { guidelines }\end{array}$ & $\begin{array}{l}\text { Develop methods how to } \\
\text { create a safe work } \\
\text { environment }\end{array}$ & $\begin{array}{l}\text { Senior (internal), } \\
\text { senior (external), } \\
\text { specialist }\end{array}$ & 11 & 5 \\
\hline
\end{tabular}

* One interview with project manager for SE and SP (same person on both teams). ${ }^{* *}$ One interview with project manager for IE and EE (same person on both teams). 
Table 2: Overview of the open service innovation archetypes.

\begin{tabular}{|c|c|c|c|}
\hline & $\begin{array}{l}\text { Internal Group } \\
\text { Development }\end{array}$ & $\begin{array}{l}\text { Satellite Team } \\
\text { Development }\end{array}$ & Rocket Team Development \\
\hline Purpose of the group & $\begin{array}{l}\text { Incremental service } \\
\text { innovation }\end{array}$ & $\begin{array}{l}\text { Incremental service } \\
\text { innovation }\end{array}$ & Radical service innovation \\
\hline Description & $\begin{array}{l}\text { Maintenance and } \\
\text { improvements of existing } \\
\text { offerings }\end{array}$ & $\begin{array}{l}\text { Maintenance and } \\
\text { improvements of existing } \\
\text { offerings }\end{array}$ & $\begin{array}{l}\text { Development of new } \\
\text { offerings }\end{array}$ \\
\hline $\begin{array}{l}\text { Organizing co-creation } \\
\text { among participants }\end{array}$ & Homogeneous competences & Homogeneous competences & $\begin{array}{l}\text { Heterogeneous } \\
\text { competences }\end{array}$ \\
\hline \multirow[t]{5}{*}{$\begin{array}{l}\text { Organizing development } \\
\text { work }\end{array}$} & \multirow{5}{*}{$\begin{array}{l}\text { Development within the } \\
\text { open service innovation } \\
\text { group. } \\
\text { Senior participants perform } \\
\text { the development work. } \\
\text { Innovator firm finish and } \\
\text { "package" service for } \\
\text { market. }\end{array}$} & $\begin{array}{l}\text { Development in integrated } \\
\text { development teams. }\end{array}$ & $\begin{array}{l}\text { Development in integrated } \\
\text { development teams. }\end{array}$ \\
\hline & & \multirow{3}{*}{$\begin{array}{l}\text { Senior participants from } \\
\text { open service innovation } \\
\text { group in charge involving } \\
\text { specialists in development } \\
\text { work. }\end{array}$} & \multirow{3}{*}{$\begin{array}{l}\text { Senior participants from } \\
\text { open service innovation } \\
\text { groups or external experts } \\
\text { in charge. }\end{array}$} \\
\hline & & & \\
\hline & & & \\
\hline & & $\begin{array}{l}\text { work. } \\
\text { Open service innovation } \\
\text { group makes decisions and } \\
\text { innovator firm finishes and } \\
\text { "packages" service for the } \\
\text { market. }\end{array}$ & $\begin{array}{l}\text { Open service innovation } \\
\text { group makes decisions and } \\
\text { the innovator firm finishes } \\
\text { and "packages" services for } \\
\text { the market. }\end{array}$ \\
\hline Ties between participants & Deep and formal & Deep & Wide and informal \\
\hline $\begin{array}{l}\text { Examples of open } \\
\text { innovation groups }\end{array}$ & $\begin{array}{l}\text { Delivery contract, Inventory } \\
\text { database, Structural } \\
\text { engineering }\end{array}$ & $\begin{array}{l}\text { Mechanical engineering, } \\
\text { Instrument engineering, } \\
\text { Electrical engineering, Pipe } \\
\text { engineering }\end{array}$ & Surface protection, Safety \\
\hline
\end{tabular}


Figure 1: Archetypes of open service innovation.

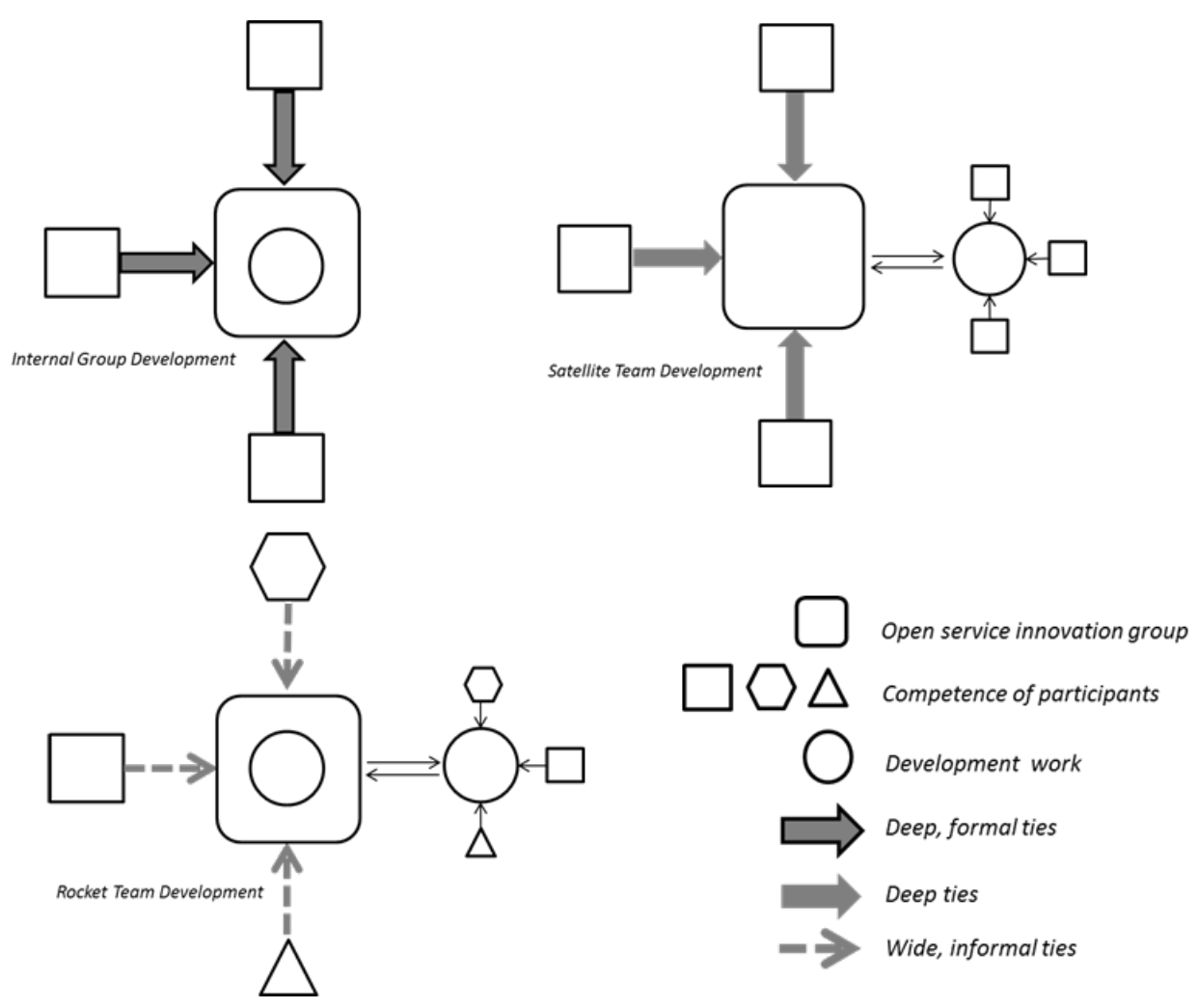


Appendix: Quotes from the investigated open service innovation groups.

\begin{tabular}{|c|c|c|c|c|}
\hline Innovation group & Purpose of the group & Role of participants & Role of project manager (PM) & Development work \\
\hline Delivery contract & $\begin{array}{l}\text { It's a standardization how to carry } \\
\text { through procurements. The contract is a } \\
\text { collection of experience during many, } \\
\text { many years of procurements. }\end{array}$ & $\begin{array}{l}\text { We need pepople with profound } \\
\text { experience of procurement } \\
\text { work, such as purchase } \\
\text { managers, and business lawers }\end{array}$ & $\begin{array}{l}\text { You send all information to the } \\
\text { PM, because she is like the } \\
\text { spider in the web. }\end{array}$ & $\begin{array}{l}\text { I rather say we work together } \\
\text { plenary but sometimes we also } \\
\text { work in sub-groups if certain } \\
\text { competence is needed. }\end{array}$ \\
\hline Inventory database & $\begin{array}{l}\text { Our objective is to help the industry to } \\
\text { earn money, increase availability and to } \\
\text { reduce costs. }\end{array}$ & $\begin{array}{l}\text { In our group there is a spread } \\
\text { from purchase manangers to } \\
\text { store house managers. }\end{array}$ & $\begin{array}{l}\text { To a high extent it's the PM } \\
\text { who collects information and } \\
\text { reports during the meetings }\end{array}$ & $\begin{array}{l}\text { Normally, but not always, there } \\
\text { are members from the } \\
\text { innovation group in the } \\
\text { development teams. }\end{array}$ \\
\hline Structural engineering & $\begin{array}{l}\text { I have not been part of the development } \\
\text { of a new standard rather we update } \\
\text { existing standards }\end{array}$ & $\begin{array}{l}\text { We don't have the time to } \\
\text { engage in finding solutions, } \\
\text { making calculations and } \\
\text { blueprints so we have two } \\
\text { technical consultants in the } \\
\text { group. }\end{array}$ & $\begin{array}{l}\text { We tell the PM what to write in } \\
\text { the documents [what to become } \\
\text { updated standards] and then she } \\
\text { takes care of that. }\end{array}$ & $\begin{array}{l}\text { A few members are selected for } \\
\text { a development team, normally } \\
\text { two from the industry and one } \\
\text { technical consultant. }\end{array}$ \\
\hline $\begin{array}{l}\text { Mechanical } \\
\text { engineering }\end{array}$ & $\begin{array}{l}\text { We work with standards and guidelines } \\
\text { for the pulp and paper industry, during } \\
\text { my ten years it's very few new standards } \\
\text { we have developed. }\end{array}$ & $\begin{array}{l}\text { In this group we have mostly } \\
\text { managers or engineers from the } \\
\text { mechanical projection } \\
\text { department or one to two } \\
\text { maintenace managers }\end{array}$ & $\begin{array}{l}\text { The PM is very dedicated and } \\
\text { have a positive view, lots of } \\
\text { things are happening all the } \\
\text { time }\end{array}$ & $\begin{array}{l}\text { Then we go to our firms and } \\
\text { look for suitable persons to join } \\
\text { the development team. We [the } \\
\text { innovation group members] are } \\
\text { never part of the development } \\
\text { teams. }\end{array}$ \\
\hline Instrument enginering & $\begin{array}{l}\text { We are a group with participants from the } \\
\text { owner companies with the objectives to } \\
\text { update standards. }\end{array}$ & $\begin{array}{l}\text { We are, engineers on pulp and } \\
\text { paper plants working with } \\
\text { instrument and automation } \\
\text { issues, We are "automation- } \\
\text { people” }\end{array}$ & $\begin{array}{l}\text { I guess the PM] is part of all } \\
\text { development teams, because he } \\
\text { takes notes and keep track of } \\
\text { the agenda and so forth. }\end{array}$ & $\begin{array}{l}\text { Normally there is a member } \\
\text { from the innovation group who } \\
\text { is in charge for the work to be } \\
\text { done. }\end{array}$ \\
\hline Electrical engineering & $\begin{array}{l}\text { The majority of the job is to update the } \\
\text { standards and guidelines I would say. }\end{array}$ & $\begin{array}{l}\text { It's all electrical engineers with } \\
\text { responsibility for the power } \\
\text { supply to the pulp and paper } \\
\text { plants, most of us work with } \\
\text { both projecting and maintenace, } \\
\text { we are "electrician-people” }\end{array}$ & $\begin{array}{l}\text { The PM don't need to be part of } \\
\text { all development teams. }\end{array}$ & $\begin{array}{l}\text { For this we need a development } \\
\text { team and then we select a } \\
\text { person in charge. It's in the } \\
\text { development teams the real } \\
\text { work takes place. }\end{array}$ \\
\hline Pipe engineering & It's an existing standard we need to & $\begin{array}{l}\text { It's a mix of people, skilled and } \\
\text { competent engineers, project }\end{array}$ & $\begin{array}{l}\text { The PM is part of every } \\
\text { development team. The PM put }\end{array}$ & $\begin{array}{l}\text { We form a development team } \\
\text { and they work hard to get it }\end{array}$ \\
\hline
\end{tabular}


managers, maintenance

managers and consultants.

The purpose is to have a broad

innovation group to be able to create

complete standards to support

procurements of surface protection

Safety

It's a multi-technical innovation group

with representation from other innovation groups who deals with workplace safetyrelated questions.
Half of the members are from

the pulp and paper industry, and

then there is a surface

protection inspector, several

paint manufacturers and a paint

entrepreneur

You need to have the right

composition of knowledge and

competence. Most of the

members work with work

environment and work safety-

related issues. a price on the offering and

release it on the market.

She is part of many of the

development teams as a

secretary. She is like a spider in

the web, make sure the

development teams are formed, and keep them going.

The PM keeps track on the

development teams since they are engaged full time. done as fast as they can. It's

there where the actual work is

done. During the development

work we sometimes ask

external experts for advice.

The development team is kept

within the innovation group.

It's not the development group

but the innovation group who

make decisions.

If there is an idea that has potential we first conduct a prestudy. We want the person in

charge of the development

group to be a member of the innovation group. 
APPENDIX:

\begin{tabular}{|c|c|c|c|c|}
\hline Innovation group & Objectives & Role of participants & Role of project manager (PM) & Development work \\
\hline $\begin{array}{l}\text { Delivery Contract } \\
\text { (DC) }\end{array}$ & $\begin{array}{l}\text { It's a standardization how to carry } \\
\text { through procurements. The contract is a } \\
\text { collection of experience during many, } \\
\text { many years of procurements. }\end{array}$ & $\begin{array}{l}\text { We need pepople with profound } \\
\text { experience of procurement } \\
\text { work and often it is purchase } \\
\text { managers, and normally 2-3 } \\
\text { business lawers }\end{array}$ & $\begin{array}{l}\text { You send all information to the } \\
\text { PM, because she is like the } \\
\text { spider in the web. }\end{array}$ & $\begin{array}{l}\text { I rather say we work together } \\
\text { plenary but sometimes we also } \\
\text { work in sub-groups if certain } \\
\text { competence is needed. }\end{array}$ \\
\hline
\end{tabular}

Inventory Database Our objective is to help the industry to earn money, increase availability and to reduce costs.

I have not been part of the development of a new standard rather we update existing standards

Engineering (SE)

Mechanical

Engineering (ME)

We work with standards and guidelines for the pulp and paper industry, during my ten years it's very few new standards we have developed.

Instrument Enginering We are a group with participants from the (IE) owner companies with the objectives to update standards.

Electrical Engineering
In our group there is a spread from purchase manangers to store house managers.
To a high extent it's the PM who collects information and reports during the meetings

Normally I would say there are members from the innovation group in the development teams. Occasionally we have development teams without the PM or members from the innovation group.

We don't have the time or energy to engage in finding solutions, making calculations and blueprints so we have invited two technical consultants to the group.

In this group we have mostly managers or engineers from the mechanical projection department or one to two maintenace managers

We are, engineers on pulp and paper plants working with instrument and automation issues, We are "automationpeople”

It's all electrical engineers with responsibility for the power supply to the pulp and paper plants, most of us work with
We tell the PM what to write in the documents [what to become updated standards] and then she takes care of that.

The PM is very dedicated and have a positive view, lots of things are happening all the time

I guess the $\mathrm{PM}$ ] is part of all development teams, because he takes notes and keep track of the agenda and so forth.

The PM don't need to be part of all development teams.
A few members are selected for a development team, normally two from the industry and one technical consultant.

Then we go to our firms and look for suitable persons to join the development team. We [the innovation group members] are never part of the development teams.

Normally there is a member from the innovation group who is in charge for the work to be done.

For this we need a development team and then we select a person in charge. It's in the development teams the rea 
Pipe Engineering (PE) It's an existing standard we need to update or maybe a complete new one.

Surface Protection

Safety (S)
The purpose is to have a broad innovation group to be able to create complete standards to support procurements of surface protection

It's a multi-technical innovation group with representation from other innovation groups who deals with workplace safetyrelated questions.
It's a mix of people, skilled and competent engineers, project managers, maintenance managers and consultants.

Half of the members are from the pulp and paper industry, and then there is a surface

protection inspector, several

paint manufacturers and a paint entrepreneur

You need to have the right composition of knowledges and competences, sometimes you need the width and sometimes

you need a narrow focus. Most of the members work with work environment and work safety-

related issues.
The PM is part of every development team. The PM put a price on the offering and release it on the market.

She is part of many of the development teams as a secretary. She is like a spider in the web, make sure the development teams are formed, and keep them going.

The PM keeps track on the development teams since they are engaged full time.
We form a development team and they work hard to get it done as fast as they can. It's there where the actual work is done. During the development work we sometimes ask external experts for advice.

The development team is kept within the innovation group. It's not the development group but the innovation group who make decisions.

If there is an idea that has potential we first conduct a prestudy to find out if it still is interesting to continue further.

We want the person in charge of the development group to be a member of the innovation group. 